International Journal of Food Science, Nutrition and Dietetics (IJFS)

ISSN 2326-3350

\title{
Quality Evaluation Of Bread Incorporated With Different Levels Cinnamon Powder
}

Dhillon G K*, Amarjeet K

* Department of Food Science and Technology, Punjab Agricultural University, Punjab, India.

\section{Abstract}

Cinnamon powder was substituted $(0,1,2,3$ and $4 \%)$ in wheat flour for bread making. Baking, sensory and storage quality of bread were analyzed and compared with white bread. Cinnamon powder was found to have high total phenol content (TPC) and antioxidant activity. The highest TPC (0.94 mg GAE/DW) and antioxidant activity (27.67\%) were observed in the bread containing highest level of cinnamon powder $(4 \%)$. But loaf volume and sensory scores were less at this level of incorporation. Results suggested that among the studied samples, bread with $2 \%$ of cinnamon powder showed improved baking and textural properties with maximum overall acceptability by panelist and had a shelf life of 6 days at room temperature $\left(30 \pm 5^{\circ} \mathrm{C}\right)$.

Key Words: Cinnamon; Bread; Antioxidant Activity; Total Phenol Content; Shelf-Life.

\author{
*Corresponding Author: \\ Gurpreet K Dhillon \\ Department of Food Science and Technology, \\ Punjab Agricultural University, Punjab, India. \\ Tel: 91-0161-2401965 Extn: 305 \\ E-mail: gurpreet1183@gmail.com
}

Received: October 08, 2013

Accepted: October 29, 2013

Published: October 30, 2013

Citation: Dhillon G K, Amarjeet K (2013) Quality Evaluation of read Incorporated With Different Levels of Cinnamon Powder. Int J Food Sci Nutr Diet. 2(7), 70-74. doi: http://dx.doi.org/10.19070/2326-33501300013

Copyright: Dhillon G K. ${ }^{\circ} 2013$ This is an open-access article distributed under the terms of the Creative Commons Attribution License, which permits unrestricted use, distribution and reproduction in any medium, provided the original author and source are credited.

\section{Introduction}

Functional foods have been the topic of considerable interest in the food and nutrition industry for years. In developing functional bakery products it is important to develop a product with physiological effectiveness and consumer's acceptance in terms of appearance, taste and texture (Siro et al., 2008). Bread is an important staple food made of wheat flour, salt and yeast, and consumed worldwide (Fan et al., 2006). Consumers prefer to eat healthier foods in order to prevent non-communicable diseases. For this reason, industry and researchers are involved in optimizing bread making technology to improve the variety, quality and taste (Hathorn et al., 2008, Dewettinck et al., 2008). Spices and herbs being natural antioxidant and antimicrobial agents have great potential to be used as functional ingredients in the bread formulation. Studies have been carried out of find potential sources of natural antioxidant in wheat bread. Lin et al., (2009) found that buckwheat could be incorporated into wheat bread to get better functional composition and improved antioxidant properties. Peng et al., (2010) also reported an increased antioxidant content of bread fortified with grape seed extract-fortified bread. Lim et al., (2011) evaluated antioxidant and quality of bread containing turmeric.

The genus Cinnamomum (family: Lauraceae) is valued for its dried inner bark of the tree C. verum. Cinnamon oleoresin is used mainly for flavouring food products such as cakes and confectionary. Cinnamon is known for its high total phenol content and antioxidant activity (Jay 1996), which accelerates its use in bread. Apart from health benefits of being a natural antioxidant, cinnamon possess strong antimicrobial properties to act as natural preservatives in bread. Inhibitory effects of cinnamaldehyde and eugenol against Aspergillus niger, major spoilage mold of fruits and nuts were studied by Matan (2007). Result showed that Cinnamaldehyde and eugenol are natural antimicrobial additives to inhibit growth of A. niger in stored fruits and nuts. Present study was conducted to study the effect of cinnamon incorporation on improvement of quality of bread.

\section{Material and Methods}

\section{Materials}

The cinnamon powder was purchased from a local market, dried, grounded, packed in sterilized plastic bags and treated in microwave for $915 \mathrm{MHz}$ for $1 \mathrm{~min}$.

\section{Physicochemical properties of raw materials}

Prescribed protocols of AACC (AACC 2010) procedures for moisture, fat, ash, protein and fibre were thoroughly followed.

\section{Determination of anti-oxidant activity of cinnamon}

The antioxidant activities of cinnamon powder was evaluated through free radical scavenging effect on 1,1-diphenyl-2-picrylhydrazyl (DPPH) radical. The determination was based on the 
method proposed by Akowuah et al., (2005).

Percentage of DPPH scavenging activity was calculated as

$\%$ inhibition of DPPH $=[$ Abs control - Abs sample $/$ Abs control] $\times 100$

\section{Determination of total phenol content}

Total phenolic contents of all plants extracts were determined using Folin-Ciocalteu reagent as described by Singlaton \& Rossi (1965). Samples were inserted into different test tube and mixed thoroughly with $5 \mathrm{ml}$ Folin-Ciocalteu reagent (previously predilute 10 times with distilled water). After 5 mins, $4 \mathrm{ml}$ of $7.5 \%$ sodium carbonate was added and allowed to react for $2 \mathrm{hrs}$ at room temperature. The absorbance was measured at $765 \mathrm{~nm}$ using spectrophotometers. Samples were measured in three replicates. Standard curve of gallic acid solution (10, 20, 40, 60, 80 and $100 \mathrm{ppm}$ ) was prepared using the similar procedure. The results were expressed as $\mathrm{mg}$ GAE/100 $\mathrm{g}$ extract sample.

\section{Bread}

Straight dough AACC method (Anonymous, 1990) numbered 10 -10 B was followed. The formula for control was as: flour-100 g, Compressed yeast-3.0 g, Sugar-2.5 g, Bakery shortening-2.0 g, Salt / NaCl-1.0 g, Potassium bromated 1 ppm, Water Optimum. The dough was prepared and baking schedule is given as: Fermentation-45 min, Remixing-25 sec, Recovery-20 min, Sheeting and moulding-3 min, Proofing (at 86 o F, RH 75 percent)- 55 min, Baking- $25 \mathrm{~min}$ at $450^{\circ} \mathrm{F}$.

\section{Bread quality}

The loaves were analyzed for volume,specific volume and height.

Table 1: Chemical composition, total phenol and antioxidant activity of raw material

\begin{tabular}{|l|l|l|l|l|l|l|l|}
\hline Samples & $\begin{array}{l}\text { Moisture } \\
(\mathbf{\%})\end{array}$ & $\begin{array}{l}\text { Protein } \\
\mathbf{( \% )}\end{array}$ & $\begin{array}{l}\text { Fat } \\
\mathbf{( \% )}\end{array}$ & $\begin{array}{l}\text { Ash } \\
\mathbf{( \% )}\end{array}$ & $\begin{array}{l}\text { Fibre } \\
\mathbf{( \% )}\end{array}$ & $\begin{array}{l}\text { Total phenol content } \\
(\mathbf{m g} \text { GAE/100g DW) }\end{array}$ & $\begin{array}{l}\text { Antioxidant activity } \\
(\mathbf{D P P H} \% \text { inhibition })\end{array}$ \\
\hline Wheat flour & $12.03^{\mathrm{b}}$ & $9.17^{\mathrm{a}}$ & $1.57^{\mathrm{a}}$ & $0.54^{\mathrm{a}}$ & $0.49^{\mathrm{a}}$ & $3.78^{\mathrm{a}}$ & $17^{\mathrm{a}}$ \\
\hline $\begin{array}{l}\text { Cinnamon } \\
\text { powder }\end{array}$ & $10.43^{\mathrm{a}}$ & $8.37^{\mathrm{b}}$ & $2.45^{\mathrm{b}}$ & $3.41^{\mathrm{b}}$ & $27.29^{\mathrm{b}}$ & $82.39^{\mathrm{b}}$ & $89^{\mathrm{b}}$ \\
\hline
\end{tabular}

\section{Sensory quality}

Sensory evaluation for appearance, color, texture, flavor and overall acceptability was carried out the next day by a panel of minimum ten semi trained judges on nine point hedonic scale (Larmond, 1970).

\section{Texture analysis}

The TPA (Texture profile analysis) of bread and muffins were analysed by Stable Micro System Texture Analyser Model (TA-H di England) using settings as Test-TPA, Probe-75 mm Cylindrical, Pre-test speed-1 mm/s, Test speed- $1 \mathrm{~mm} / \mathrm{s}$, Post-test speed-1 $\mathrm{mm}$, Force- $250 \mathrm{~kg}$

\section{Microbial studies}

Bread samples were packed in low density polyethylene bags and analyzed for visual mold growth for a week at room temperature $\left(30 \pm 5^{0} \mathrm{C}\right)$

\section{Statistical Analysis of data}

The data collected on different characteristics were analysed with the help the software CPCS-1(Singh et al., 1991). All results were expressed at $14 \%$ moisture basis unless otherwise stated. Each value was mean of three observations.

\section{Results and Discussion}

Results for proximate composition, total phenolic content and antioxidant activity of cinnamon powder are shown in Table 1. Cinnamon powder was found to be rich in fibre (27.29\%) and also contained appreciable amount of protein $(8.37 \%)$.

\section{Effect of cinnamon powder on baking quality of bread}

The bread-baking data are shown in Table 2. The cinnamon was incorporated at $0,1,2,3$ and $4 \%$ into the flour for bread making. Significant variations were observed in various quality parameters of cinnamon bread. Baking absorption increased significantly with incorporation of cinnamon powder at different levels in comparison to control. At 1\% level of incorporation, baking absorption was $72.43 \%$ and it increased to $78 \%$ at $4 \%$ level of incorporation. This might have been due to high fibre content of added cinnamon powder. Loaf weight increased with increasing level of incorporation in comparison to control.

Loaf weight was $147 \mathrm{~g}$ at $1 \%$ level of cinnamon powder and increased to $150 \mathrm{~g}$ at $4 \%$ level. The increase in bread weight might have been due to increased water retention. Loaf volume and height increased up to $2 \%$ level of addition and there after these parameters decreased as incorporation of cinnamon powder increased. The decreasing loaf volume was due to the dilution of gluten protein, present in wheat flour (Pomeranz et al., 1977) and also could have resulted from the interaction between gluten and fiber material of spices and herbs.

Effect of incorporation of cinnamon powder on the organoleptic quality of bread

Variations were observed regarding organoleptic quality (appearance, color, texture, flavor and overall acceptability) of bread when evaluated by semi-trained panel of judges on nine point hedonic scale (Table 3). Appearance and color scores were high at $2 \%$ and $3 \%$ level of cinnamon powder in the bread. Maximum acceptability of flavor was observed at $2 \%$ level of incorporation of cinnamon in bread. Cinnamon bread had higher overall acceptability (8.15 and 8.44$)$ at $1 \%$ and $2 \%$ respectively than control. Sensory properties of bread made with low levels of onion and garlic powders were good and some panelists preferred that over control (Faheid 1999). 
Table 2: Effect of incorporation of cinnamon powder on baking quality of bread

\begin{tabular}{|l|l|l|l|l|l|l|}
\hline Samples & Level (\%) & Baking absorption (\%) & Loaf height (cm) & Loaf weight (g) & Loaf volume (cc) & $\begin{array}{l}\text { Specific } \\
\text { volume (cc/g) }\end{array}$ \\
\hline Control & 0 & $70.12^{\mathrm{a}}$ & $9.21^{\mathrm{a}}$ & $145^{\mathrm{a}}$ & $685^{\mathrm{a}}$ & $4.72^{\mathrm{a}}$ \\
\hline \multirow{5}{*}{ Cinnamon } & 1 & $72.34^{\mathrm{b}}$ & $9.34^{\mathrm{b}}$ & $147^{\mathrm{b}}$ & $700^{\mathrm{b}}$ & $4.76^{\mathrm{a}}$ \\
\cline { 2 - 7 } & 2 & $73.89^{\mathrm{c}}$ & $9.41^{\mathrm{c}}$ & $149^{\mathrm{c}}$ & $710^{\mathrm{c}}$ & $4.76^{\mathrm{a}}$ \\
\cline { 2 - 7 } & 3 & $75.67^{\mathrm{d}}$ & $9.20^{\mathrm{d}}$ & $150^{\mathrm{d}}$ & $650^{\mathrm{d}}$ & $4.33^{\mathrm{b}}$ \\
\cline { 2 - 6 } & 4 & $78.00^{\mathrm{e}}$ & $8.93^{\mathrm{e}}$ & $152^{\mathrm{e}}$ & $634^{\mathrm{c}}$ & $4.17^{\mathrm{c}}$ \\
\hline
\end{tabular}

Table 3: Effect of incorporation of cinnamon powder on the mean sensory panel scores (Max 9) of bread

\begin{tabular}{|l|l|l|l|l|l|l|}
\hline \multirow{2}{*}{ Samples } & \multirow{2}{*}{$\begin{array}{l}\text { Level } \\
\mathbf{( \% )}\end{array}$} & \multicolumn{5}{|c|}{ Parameters } \\
\cline { 3 - 7 } & Appearance & Color & Texture & Flavor & Overall acceptability \\
\hline Control & 0 & $8.00^{\mathrm{b}}$ & $8.10^{\mathrm{b}}$ & $8.00^{\mathrm{b}}$ & $7.50^{\mathrm{a}}$ & $7.90^{\mathrm{b}}$ \\
\hline \multirow{3}{*}{ Cinnamon } & 1 & $8.06^{\mathrm{c}}$ & $8.43^{\mathrm{d}}$ & $8.07^{\mathrm{c}}$ & $8.05^{\mathrm{b}}$ & $8.15^{\mathrm{c}}$ \\
\cline { 2 - 7 } & 2 & $8.40^{\mathrm{e}}$ & $8.53^{\mathrm{e}}$ & $8.54^{\mathrm{d}}$ & $8.16^{\mathrm{c}}$ & $8.44^{\mathrm{d}}$ \\
\cline { 2 - 7 } & 3 & $8.30^{\mathrm{d}}$ & $8.26^{\mathrm{c}}$ & $7.60^{\mathrm{a}}$ & $7.53^{\mathrm{a}}$ & $7.93^{\mathrm{b}}$ \\
\cline { 2 - 7 } & 4 & $7.40^{\mathrm{a}}$ & $8.00^{\mathrm{a}}$ & $7.60^{\mathrm{a}}$ & $7.60^{\mathrm{a}}$ & $7.64^{\mathrm{a}}$ \\
\hline
\end{tabular}

\section{Effect of cinnamon powder on textural properties of bread}

Texture analysis is primarily concerned with the evaluation of mechanical characteristics where a material is subjected to a controlled force from which a deformation curve of its response is generated. The primary characteristics parameters are the hardness, springiness, adhesiveness and cohesiveness (Szczesniak et al., 1963). Textural properties of bread prepared after addition of cinnamon powder are presented in Table 4.

A significant increase was observed at $4 \%$ level of cinnamon powder in the bread. Gumminess which is mutually exclusive with chewiness (Szczesniak et al., 1995) is often employed to characterize the energy to disintegrate semi-solid foods (chewiness is for solid products) and could nicely correlated to sensory evaluations by trained texture profile panel (Truong et al., 1997). Since gum- miness is dependent on hardness, similar influence trends were observed. Cinnamon powder significantly increased the gumminess of bread at $4 \%$ level as compared to control. Gumminess was 1.13 at $1 \%$ which increased to 1.37 at $4 \%$ level. Cinnamon powder increased the chewiness of bread. At $1 \%$ level, chewiness was 1.06 which significantly increased to 1.37 at $4 \%$ level.

Effect of cinnamon powder on microbiological quality of bread

Effect of cinnamon powder on visual mold growth is given in Table 5. Control bread which contained no chemical preservative spoiled within 4 days. Bread prepared with $2 \%$ cinnamon powder had no mold growth for 6 days. Inhibitory effect of cinnamalde hyde and eugenol on mold growth was also reported by Bullerman et al. (1977) and Matan (2007).

Table 4: Effect of incorporation of cinnamon powder on the textural properties of bread

\begin{tabular}{|l|l|l|l|l|l|l|}
\hline Samples & \multirow{2}{*}{ Level (\%) } & \multicolumn{5}{|c|}{ Parameters } \\
\cline { 3 - 7 } & & Hardness $(\mathrm{Kg})$ & Springiness $(\mathrm{mm})$ & Cohesiveness & Gumminess $(\mathrm{N})$ & Chewiness $\left(\mathrm{N}^{*} \mathrm{~mm}\right)$ \\
\hline Control & 0 & $1.39^{\mathrm{a}}$ & $0.98^{\mathrm{a}}$ & $0.82^{\mathrm{a}}$ & $1.13^{\mathrm{a}}$ & $1.11^{\mathrm{b}}$ \\
\hline \multirow{3}{*}{ Cinnamon } & 1 & $1.38^{\mathrm{a}}$ & $0.94^{\mathrm{a}}$ & $0.82^{\mathrm{a}}$ & $1.13^{\mathrm{a}}$ & $1.06^{\mathrm{a}}$ \\
\cline { 2 - 7 } & 2 & $1.41^{\mathrm{a}}$ & $0.91^{\mathrm{a}}$ & $0.83^{\mathrm{a}}$ & $1.17^{\mathrm{a}}$ & $1.06^{\mathrm{a}}$ \\
\cline { 2 - 7 } & 3 & $1.45^{\mathrm{a}}$ & $0.95^{\mathrm{a}}$ & $0.85^{\mathrm{a}}$ & $1.23^{\mathrm{a}}$ & $1.17^{\mathrm{b}}$ \\
\cline { 2 - 7 } & 4 & $1.58^{\mathrm{b}}$ & $0.96^{\mathrm{a}}$ & $0.87^{\mathrm{a}}$ & $1.37^{\mathrm{b}}$ & $1.31^{\mathrm{c}}$ \\
\hline
\end{tabular}

Table 5: Effect of incorporation of cinnamon powder on visual mold growth of bread stored at room temperature (30 $\pm 50 \mathrm{C})$

\begin{tabular}{|c|c|c|c|c|c|c|}
\hline \multirow[t]{3}{*}{ Samples } & \multirow{3}{*}{\begin{tabular}{|l|} 
Levels \\
$(\%)$
\end{tabular}} & \multicolumn{5}{|c|}{ Visual mold growth } \\
\hline & & \multicolumn{5}{|c|}{ Days } \\
\hline & & 0 & 2 & 4 & 6 & 8 \\
\hline Control & 0 & $\mathrm{ND}^{*}$ & ND & $\mathrm{D}^{* *}$ & $\mathrm{D}$ & $\mathrm{D}$ \\
\hline \multirow{4}{*}{ Cinnamon } & 1 & ND & ND & $\mathrm{D}$ & $\mathrm{D}$ & $\mathrm{D}$ \\
\hline & 2 & ND & ND & ND & ND & $\mathrm{D}$ \\
\hline & 3 & ND & ND & ND & $\mathrm{ND}$ & $\mathrm{D}$ \\
\hline & 4 & $\mathrm{ND}$ & ND & ND & ND & ND \\
\hline
\end{tabular}

*Not detected, ${ }^{* *}$ Detected 
Effect of cinnamon powder on composition, total phenol content and antioxidant activity of bread

The chemical composition, total phenols and antioxidant activity of cinnamon bread is given in Table 6. A significant increase in fibre and ash content were recorded in bread incorporated with cinnamon powder. Protein content of $2 \%$ and $3 \%$ level was $8.12 \%$ and $8.21 \%$, respectively. A significant increase in fibre content $(1.21 \%)$ was observed at $2 \%$ level of incorporation. Cinnamon powder had a significant contribution in increasing the antioxidant activity of bread as compared to control. Bread with $2 \%$ cinnamon had total phenol content $(0.72 \mathrm{mg}$ GAE/g DW) and antioxidant activity (16.12\%), whereas control bread had only $4.27 \%$ antioxidant activity.

\section{Conclusions}

Addition of cinnamon up to $2 \%$ resulted in increased loaf volume as compared to control, but further increase in level of incorporation significantly decreased the loaf volume of bread. Significant variations were found in sensory scores for control and formulated bread. Sensory quality results showed that incorporation of cinnamon powder at $2 \%$ level was most acceptable. Control and bread containing $2 \%$ cinnamon powder are presented in figure 1 . Cinnamon above $2 \%$ level significantly increased the hardness, gumminess and chewiness of the bread as compared to control. Bread containing $2 \%$ cinnamon had a mold free shelf life for more than 6 days and exhibited high total phenol content and antioxidant activity as compared to control.

Table 6. Effect of cinnamon powder on composition, total phenol content and antioxidant activity of bread

\begin{tabular}{|l|l|l|l|l|l|l|l|}
\hline Samples & Level (\%) & \multicolumn{7}{|c|}{ Parameters } \\
\cline { 3 - 8 } & & $\begin{array}{l}\text { Protein } \\
(\%)\end{array}$ & $\begin{array}{l}\text { Fat } \\
(\%)\end{array}$ & $\begin{array}{l}\text { Ash } \\
(\%)\end{array}$ & $\begin{array}{l}\text { Fibre } \\
(\%)\end{array}$ & $\begin{array}{l}\text { Total phenol } \\
\text { content }\end{array}$ & $\begin{array}{l}\text { Antioxidant activity } \\
(\text { DPPH } \% \text { inhibition })\end{array}$ \\
\hline Control & 0 & $8.06^{\mathrm{a}}$ & $1.47^{\mathrm{a}}$ & $0.78^{\mathrm{a}}$ & $0.50^{\mathrm{a}}$ & $0.12^{\mathrm{a}}$ & $4.27^{\mathrm{a}}$ \\
\hline \multirow{3}{*}{ Cinnamon } & 1 & $8.07^{\mathrm{a}}$ & $1.43^{\mathrm{a}}$ & $0.88^{\mathrm{b}}$ & $1.02^{\mathrm{b}}$ & $0.66^{\mathrm{b}}$ & $15.31^{\mathrm{b}}$ \\
\cline { 2 - 8 } & 2 & $8.12^{\mathrm{a}}$ & $1.47^{\mathrm{a}}$ & $1.09^{\mathrm{c}}$ & $1.21^{\mathrm{c}}$ & $0.72^{\mathrm{b}}$ & $16.12^{\mathrm{b}}$ \\
\cline { 2 - 8 } & 3 & $8.21^{\mathrm{b}}$ & $1.45^{\mathrm{a}}$ & $1.32^{\mathrm{d}}$ & $1.45^{\mathrm{d}}$ & $0.89^{\mathrm{c}}$ & $21.34^{\mathrm{c}}$ \\
\cline { 2 - 8 } & 4 & $8.37^{\mathrm{b}}$ & $1.49^{\mathrm{a}}$ & $1.97^{\mathrm{e}}$ & $1.63^{\mathrm{e}}$ & $0.94^{\mathrm{c}}$ & $27.67^{\mathrm{d}}$ \\
\hline
\end{tabular}

Fig 2: Best level (2\%) of cinnamon powder selected for bread making
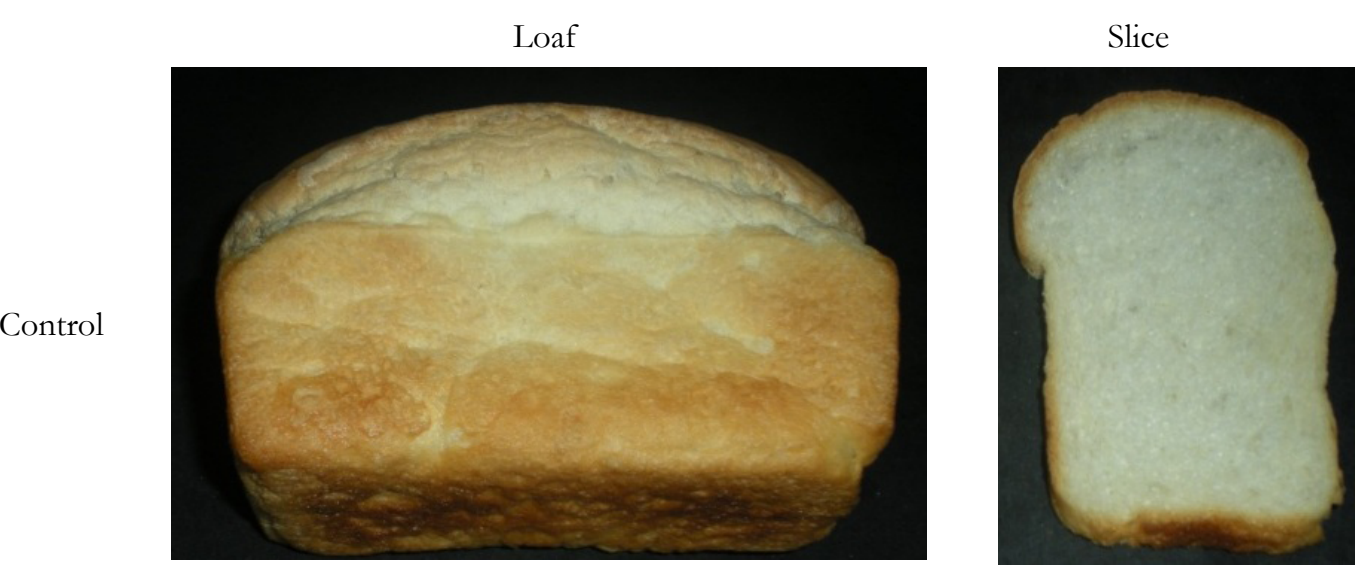

Cinnamon $(2 \%)$
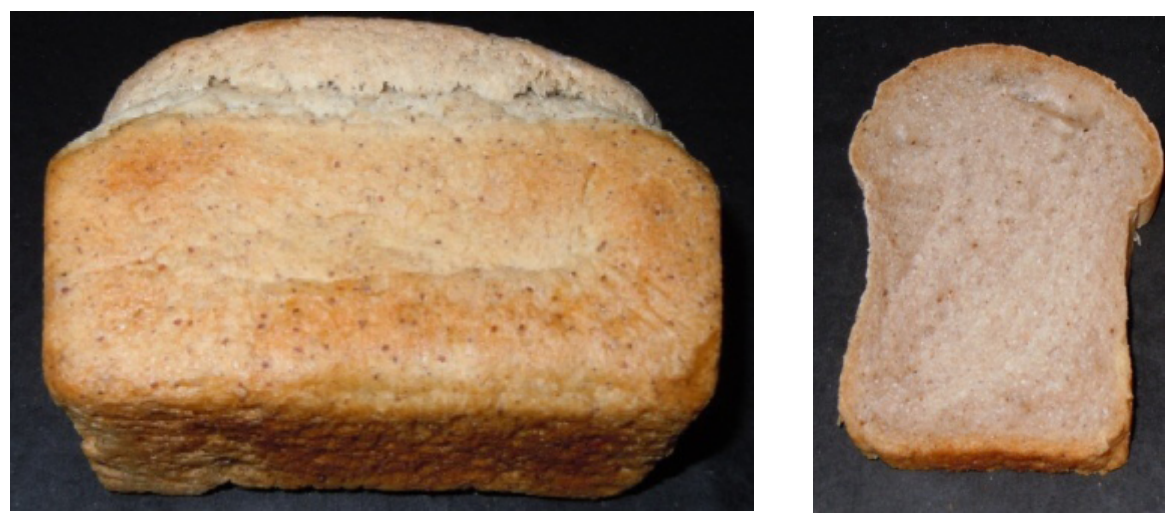


\section{References}

[1]. AACC (2010). Approved Methods of American Association of Cereal Chemists. $10^{\text {th }}$ ed. The Association St. Paul, MN.

[2]. Akowuah G A, Ismail Z, Norhayati I and Sadikun A (2005) The effects of different extraction solvents of varying polarities of polyphenols of Orthosiphonstamineus and evaluation of the free radical-scavenging activity. Food Chem 93: 311-17.

[3]. Bullerman L B, Lieu F Y and Seier S A (1977) Inhibition of growth and aflatoxin production by cinnamon and clove oils, cinnamic aldehyde and eugenol. J Food Sci 42: 1107-09, 1116.

[4]. Faheid S M M(1999) Studies on onion and garlic bread. Deutsche Lebensmittel-Rundschau 95:17-22.

[5]. Fan L, Zhang S, Yu L and Ma L (2006) Evaluation of antioxidant property and quality of breads containing Auricularia auricula polysaccharide flour. Food Chemistry 101: 1158-1163.

[6]. Hathorn C S, Biswas M A, Gichuhi P N and Bovell-Benjamin A C (2008) Comparison of chemical, physical, micro-structural, and microbial properties of breads supplemented with sweetpotato flour and high-gluten dough enhancers. LWT - Food Science and Technology 41: 803-815.
[7]. Jay J M (1996) Modern Food Microbiology. Pp. 328-46.CBS Publishers, New Delhi, India.

[8]. Larmond E (1970) Methods for sensory evaluation of Food. Can Deptt Agric Pubs 1284.

[9]. Matan (2007) Growth Inhibition of Aspergillus niger by Cinnamaldehyde and Eugenol. Walailak J Sci Technol 4: 41-51.

[10]. Pomeranz Y, Shogren M D, Finny K F and Bechtel D B (1977) Fibre in bread making- Effects on functional properties. Cereal Chem 54: 25-41.

[11]. Singleton V L and Rossi J A (1965) Colorimetry of total phenolics with phosphomolybdic phosphotungstic acid reagents. Am J Enology and Viticulture 16: 144-58.

[12]. Siro I, Kapolna E, Ka'polna B, Andrea Lugasi A (2008) Functional food. Product development, marketing and consumer acceptance-A review. $A p$ petite 51: 456-467

[13]. Szczesniak A S (1995). Letters. J Food Sci 60: 7.

[14]. Szczesniak AS (1963) Classification of textural characteristics. J Food Sci 28: 385-89.

[15]. Truong V D, Walter W M and Hamann D D (1997) Relationship between instrumental and sensory parameters of cooked sweet potato texture. J Texture Studies 28: 163-85. 